\title{
Possible Motivations for Learning English amongst Kurdish EFL Undergraduate Learners at the University Level
}

\author{
Farhad Majeed Hama ${ }^{1}$, Daiman Abdulrahman Ismael ${ }^{2}$, Aram Kamil Noori $^{3}$ \\ ${ }^{1}$ University of Sulaimani, School of Basic Education, English Dept. \\ ${ }^{2}$ University of Sulaimani, School of Basic Education, English Dept. \\ ${ }^{3}$ Institute of Training and Educational Development in Sulaimani, English Dept.
}

\begin{abstract}
It can be argued that integrative and instrumental kinds of motivation are two prominent factors in learning new languages. Each kind of motivation works differently in various contexts. Besides, several studies have been investigated in EFL (English as a foreign language), and ESL (English as a second language) settings. There are also external factors that have impacts on different types of motivation and learners. There are also obvious reasons for learning English as a foreign language. This study focused on integrative and instrumental kinds of motivation amongst Kurdish EFL undergraduate learners at the University of Sulaimani in the Iraqi Kurdistan Region. The finding showed that getting a job is a major motivator for learning English amongst learners. However, cultural and communication goals were two other important goals that encouraged learners to learn English. In general, the results revealed that instrumental motivation was more significant than integrative motivation. Additionally, some elements affected and increased learner's motivation such as parental aids, teachers, social, personality, and university environment.
\end{abstract}

Index Terms - Motivation, Instrumental Motivation, Integrative Motivation, Kurdish EFL Learners.

\section{INTRODUCTION}

It can be argued that motivation is an important construct in several academic studies. Researchers in different language learning settings have increasingly examined motivation independently. Additionally, types of motivation are a topic of serious debate concerning learning English in different ESL contexts (Khajehpour \& Ghazvini, 2011, p.1210). Motivation is one of the most important factors affecting (FLL) foreign language learning. Spolsky (1989) said the more motivation a learner has, the more time he or she will spend learning an aspect of an (SL) second language. In one of the earliest statements on motivation in (SLL) second language learning, Gardner (1985) defines motivation as referring to a combination of effort plus desire to achieve the goal of learning the language plus a favorable attitude towards learning the language. Williams and Burden (2000) mentioned that sometimes people do something because the act of doing it is enjoyable in itself. At other times, people are engaged in an activity not because they are particularly interested in the activity itself, but because performing it will help them obtain something that they want. Therefore, Csikszentmihalyi and Nakamura (1989) provide a clear definition of these concepts. Very simply, when the only reason for performing an act is to gain something outside the activity itself, such as passing an exam or obtaining financial rewards, the motivation is likely to be extrinsic. When the experience of doing something generates interest and enjoyment, and the reason for performing the activity lies within the activity itself, then the motivation is likely to be intrinsic. Intrinsically motivated activities are ones for which there is no apparent reward except the activity themselves. People seem to engage in the activities for their own sake and not because they lead to an extrinsic reward. Intrinsically motivated behaviors are aimed at bringing about internally rewarding consequences, namely feeling of competence and self-determination. Extrinsically motivated behaviors, on the other hand, are carried out in anticipation of a reward from outside and beyond the self. Typical extrinsic rewards are money, prizes, grades, and even certain types of positive feedback. Behaviors initiated solely to avoid punishment are also extrinsically motivated, even though numerous intrinsic benefits can ultimately accrue to those who, instead, view punishment avoidance as a challenge that can build their sense of competence and self-determination. Intrinsic motivation is sometimes thought to relate to long-term success. Extrinsic motivation is more related to short-term success. .

Journal of University of Human Development

Volume 7 No. 1(2021); DOI: 10.21928/juhd.v7n1y2021.pp35-42

Regular research paper: Received 30 September 2020; Accepted 18 November 2020; Published 7 February 2021

Corresponding author's e-mail: ali.univsul@gmail.com, daiman.ismael@univsul.edu.iq, aramuniv2003@gmail.com

Copyright (C) 2021 Farhad Majeed Hama, Daiman Abdulrahman Ismael, Aram Kamil Noori. This is an open access article distributed under the

Creative Commons Attribution License (CC BY-NC-ND 4.0) 


\section{PRELIMINARIES}

\section{A. Statement of the Problem}

EFL for Kurdish students at the College of Basic Education at the University of Sulaimani would shift as far as what needs to prompt them to figure out English. They would also differ in their level of English accomplishment. There ought to be a chance to be instrumental and integrative motivation sorts that inspire them to learn English and that might impact their accomplishment done English as EFL learners. It may be still obscure if alternately not this type of motivation could influence the Kurdish students' accomplishment over EFL. On the other hand, if those motivational variables prompting Kurdish students' accomplishment clinched alongside EFL were acknowledged, it might be a chance to be conceivable on the worth of effort pushing and upgrading more students to join an English language program at university and to improve their English.

\section{B. Importance of the Study}

In language learning, motivation can be assumed as a crucial variable in the students' performance while they desire to attain their aims, dreams, and ambitions. Thus, the two kinds of motivations are prominent for every learner. This study concentrates on the integrative and instrumental motivation levels of the first-year students of Sulaimani University, College of Basic Education enrolled in the year 2016-2017. Recognizing their motivation level in English language learning will incredibly help know lecturers and administrators with making an activity or exercises that will improve their English proficiency levels that they will figure worth finishing. These outcomes of this study might additionally furnish helpful guidelines for teachers apprehensive with evolving Englishlanguage instructions.

\section{Purpose of the Study}

The main purpose of this study is to indicate the reasons behind motivation in a Kurdish EFL educational setting. The following points will also discuss. Firstly, motivation and its importance for learning English in various educational contexts, particularly among a small group of Kurdish EFL learners. Secondly, this study will discuss two main types of motivation in previous EFL and ESL studies and then concerning the Kurdish EFL context. This paper will outline the most important types of motivation, which will be argued based on a short survey in the Kurdish EFL context. Next, the most vital goals of learning English will be classified as related to Kurdish motivation. Finally, the conclusion will be presented briefly.

\section{Research Questions}

To reach the objectives, the present study attempts to find answers to the following equivalent questions framed for this study

Question 1: How are Kurdish undergraduate EFL students motivated to learn the English language?

Question 2: Do the Kurdish EFL undergraduate students have instrumental and integrative motivations towards learning
English?

\section{E. Delimitation}

This study only focuses on the integrative and instrumental motivational level of Kurdish freshmen of the academic year 2016-2017. That information gathered from the questionnaire in this ponder were registered furthermore investigated as far as means, standard deviation utilizing easy calculation.

\section{Motivation}

There are several definitions of motivation and their types. Researchers have put forward various interpretations for the term motivation. For example, motivation refers to "goaldirected behavior" (Heckhausen, 1991 cited in Gardner and Masgoret, 2003, p.128). This view focuses on the importance of motivation in determining a learner's goals in doing something. Namely, Kurdish EFL learners have the goal to study English as a foreign or second language. This is tied up with the statement that 'There are abundant studies of second language/foreign language learning motivation' (Gu (Michelle), 2009, p.300). Moreover, seminal studies have been conducted by researchers' in-depth based on attitude and motivational determinants in second language learning (Gardner and Masgoret, 2003, p.123). Correspondingly, teachers and researchers have broadly accepted that motivation is the main factor that affects the success and failure of language learning (Khajehpour and Ghazvini, 2011; Oruc and BektasCetinkaya, 2010). These arguments are in agreement with Al Rifai's findings (2010, p.5216) reveal that learners need the motivation to learn a second language. However, there is an inconsistency with motivational concepts in various studies. In other words, studies have dealt with motivation in different constraints. For example, psychological frameworks such as self-determination (Brown, 1994) and linguistic selfconfidence (Clement, Dornyei \& Noels, 1994), social and psychological factors (Gardner \& Lambert, 1972; Gardner, 1985; Giles \& Byrne, 1982) and social frameworks (Schumann,1986; Norton, 2000 as cited in Bernard, 2010, p4 and p5). These studies might show the complexity of motivation construct in other studies, especially in language learning contexts.

To justify the reasons for learning English and indicate motivation among Kurdish EFL learners appropriately, motivation should be debated based on cultural and educational contexts. With the viewpoint of Gardner $(2007,13)$ these two concepts are crucially considerable in highlighting motivation for individual learners. Concerning language learning, Kurdish EFL learners have different attitudes, which can be applied to foreign language learning motivation throughout their own educational and cultural views, personal features, ideals, etc.

Concerning teaching experiences, Kurdish EFL learners have possible incentives to learn English as a foreign language in Kurdistan. Nevertheless, it might not be easy to investigate the motivation construct in the Kurdish educational setting since sufficient studies might not be available in Kurdish, 
particularly in the EFL context.

\section{Foreign LANGUAGE LEARNING Motivation}

However, there are notional differences in the researcher's views. Several studies indicate that motivation is linked with an individual's selection of a specific activity, perseverance with it, and effort spent on it (Manolopoulou-Sergi, 2004, p.428). This definition can be applied to individual learners, including Kurdish learners to acquire EFL. The English language has its importance for individuals in each society. Because of this, several reasons should be addressed concerning motivating learners. For instance, Johnson (2008, p.5) shows the reasons for five learners who want to learn a foreign language. For example, one of them learns English for educational purposes. In the same way, Crystal (2007, p.432) indicates some significant points in foreign language learning, in particular, English, such as English being an international language. Another example is that Kurdish students are stimulated to learn English in Newcastle city in the UK as second language learners of English. Similarly, Kurdish students are motivated by various factors to learn English in Kurdistan. As stated earlier, motivation is a key factor in learning English in ESL contexts. It is also crucial in several EFL contexts. Motivation in Kurdish EFL contexts can be determined by EFL studies from different backgrounds such as Turkish, Malaysian, etc. Above all, it is necessary to be more specific in discussing motivation among individual learners in educational contexts since this research mainly focuses on learners' motivation in the College of Basic Education in Kurdistan. In most cases, the most effective theories in the field of language learning are socio-educational and socio-cultural motivation (Gardner, 1985; Garndner et al., 2004; cited in Koul, et al., 2009). These arguments are in agreement with Dörnyei (1990) who argues that learners are incited to learn a foreign language for integrative and instrumental reasons. According to (Gardner, 1985; Gardner et al., 2005; also Dornyei, 1990, 2006), integrative and instrumental motivations are essential to differentiate individual learners in their motivation to learn languages (Koul, 2009, p.677). These two types of motivation are also important in separating the goals of learning English amongst Kurdish EFL learners. Therefore, they can be applied to Kurdish educational contexts. Nevertheless, there is not sufficient literature on motivation in the Kurdish context.

\section{IMPLICATIONS OF INTEGRATIVE AND INSTRUMENTAL MOTIVATION}

Based on teaching experience, a short survey, recent studies on these kinds of motivation, and the English curriculum in Kurdistan, two types of motivation can be debated in detail. Several studies will be helpful to categorize the contribution to the comprehending of motivation in an academic framework in second or foreign language learning particularly. Theories such as integrative motivation and self-determination originating in the social-psychological period focused on second language motivation. (Bernard, 2010, p.3). All views will be helpful to imply the two types of motivation in the Kurdish EFL context.

\section{A. Instrumental Motivation}

This refers to practical reasons for learning languages such a finding a better career or passing an exam. This kind of motivation seems to be seminal in several studies that have already been carried out in ESL and EFL contexts. This links with the view of Dörnyei (1990) who believes that instrumental motivation can be considered as a major key for motivating students to learn English in EFL contexts whilst integrative motivation is thought to be effective in ESL settings. These bounds up with the outcomes of several studies. For example, Turkish students are prompted to learn English to obtain instrumental goals. Besides, Khajehpour and Ghazvini (2011; p.1209) show that boys are more motivated instrumentally. On the other hand, Thai females are more instrumentally motivated than males (Koul, 2009, p.676). These debates reveal that Dörnyei's view might be true for most cases, however, different constructs such as gender might influence learners' motivation.

\section{B. Integrative Motivation}

Integrative motivation can also, be applied to those Kurdish EFL learners who are internally motivated to learn English as a foreign or second language and have a positive feeling towards people and language community culture (Gardner, 1985). Additionally, integrative motivation is different from instrumental motivation in learning a foreign language because a learner employs a general ability to get a good job in the instrumental model while integrative motivation points out the learner's goal to integrate with foreign language culture, for instance, being socially integrated by native speakers (Gardner, 1988; Gardner, Lalonde, \& Pierson, 1983 cited Bonney, 2008, p.2). This correlates with Gardner's view (2001) who explains learners' interest to integrate into the L2 community. Students' attitudes are also important in foreign or second language learning. This agrees with (Noles; Clement; Pelletier., 1999, p. 31) who view that both integrative and intrinsic motivation cites "positive attitude towards the learning situation and learning processes". This shows that a learner's positive attitude has a positive effect whereas negative attitudes can likewise unfavorably dominate motivation. These kinds of learners can be noted in the process of learning English among Kurdish EFL learners.

\section{a) Self-determination Theory}

Self-determination theory (STD) works with the idea of integrative (intrinsic) and instrumental (extrinsic) motivation. STD is a main theory of motivation, which established a set of psychological necessities such as self-sufficiency, competence, and relatedness (Ryan and Deci, 2000). These needs facilitate learners to be motivated in their learning environment such as a classroom. They also primarily work with integrative (intrinsic) motivation.

1. Autonomy: This describes a circumstance in which individual learners decide to be engaged for its internal or 
intrinsic interest (Deci and Ryan, 1987). An example would be a Kurdish EFL learner who enjoys learning English because of the inherent interest and happiness of learning English.

2. Competence: Competence refers to the need of individuals to solicit and make attempts necessary to overcome the optimum challenge. Competence illustrates the need for the ability of individual learners in their involvement in activities with a level of complexity, which is good for their skillfulness (Deci and Ryan, 1985a). Kurdish EFL learners might learn English to be competent or master the English language. Nonetheless, it could be hard to master the English language because of an absence of the English language as a target language in the Kurdish community.

3. Relatedness: This presents that learners need to be part of and to create emotional relationships with others. It reveals the desire to belong and form an intense relationship with the target language community (Baumeister and Leary, 1995). Kurdish EFL learners have this kind of feeling towards English people, as it appears in their integrative motivation (short survey, 2011).

Also, the difference between intrinsic and extrinsic motivation in STD theory is expatiated by Gardner and Lambert (1972) explain the relationship between what they name integrative and instrumental motivation in the educational setting. In their opinion, integrative motivation is like intrinsic motivation, it refers to learners' positive attitude towards the language target community whilst instrumental motivation is similar to the extrinsic motivation that highlights learners' goals to obtain external goals, for instance, passing exams or finding a job. These similarities can be applied to deal with instrumental and integrative motivation in the Kurdish EFL educational context since the primary and secondary English language curriculum was designed based on intrinsic and extrinsic motivation (Sunrise, 2011). However, integrative and instrumental kinds of motivation will be the key points in this assignment.

\section{b) Attitudes towards the English Language in the} Kurdish EFL Educational Setting

As Ortega (2009, p.172) argues that learner's attitude is crucial towards the second language community, teachers, and curriculum in the educational setting. Furthermore, based on teaching experience, two kinds of learners can be identified in Kurdish educational contexts. Those who have negative attitudes towards the above-mentioned constructs might be demotivated in learning English while some others who have a positive attitude are seemingly motivated in learning English. Besides, Kurdish students' attitudes and motivations can be discussed according to the English language curriculum, teacher, classmates, and activities that are connected with their courses of study (Gardner, 2001). A new English curriculum (Sunrise, 2011) might motivate Kurdish EFL students in primary and secondary schools since it is based on communicative language teaching. This helps learners to be able to interact with foreign cultures such as with American and British citizens. On the contrary, the old English language curriculum and some inactive teachers might have killed positive motivation among Kurdish EFL learners in the medium of education in Iraq, especially in Kurdistan in the 1990s.

\section{c) Willingness}

It can be debated whether willingness is another factor that assists learners to associate with people in the L2 community (Dörnyei, 2005). Willingness seems to be active amongst Kurdish EFL learners since a great number of students might have desires to communicate with those English foreigners who live and work in Kurdistan, particularly non-graduate students from English departments.

\section{d) The Importance of Integrative Motivation in the EFL Context}

Integrative motivation is a key factor that has an influential role in the growth of theories in foreign language learning, and motivation (Gardner, 2001 cited in Ortega, 2009, p.170) while there has been misinterpretation and criticism of this construct since the 1990s (Dörnyei, 2005, p.69). These studies (Lamb, 2004; Kaylani, 1996; Yashima, 2002 cited in Oruç and BektasÇetinkaya 2010, p.4662 and 4663) show that EFL learners do not have the chances to be consociated with the target language community as well. This situation might be a sign of the problem in most EFL contexts. It is also believed that most of the Kurdish EFL learners have the same understanding of the EFL atmosphere. This corresponds with the idea that states learners have few opportunities to practice the target language in EFL contexts (Oxford, 1990 cited in Masgoret and Gardner, 2003, p.132). In contrast, some Kurdish EFL learners have great openings to use the English language because learning the English language occupies most of the people's interests.

\section{METHODOLOGY}

\section{A. Participants}

The researchers conducted a survey on one hundred thirty Kurdish EFL students from two different English morning and evening classes at Sulaimani University, Kurdistan Region of Iraq. They ranged between twenty-one and thirty-five years of age. The participants were chosen from first and third-year students of the English Language Department in the School of Basic Education. First ear students were chosen as samples of the study because they had more exposure and motivations towards learning English. Another point is that the researchers wanted to know how lower-level students have attitudes, reactions, desires towards internal and external motivations at the beginning of their study.

\section{B. Instruments}

The learners were asked to complete a questionnaire to displays their motivation regarding learning English. Sixteen items were chosen; eight items for integrative motivation and another eight items for instrumental motivation. The questionnaire set accentuation on the motivational contrasts amongst Kurdish EFL learners that are adopted from (Al- 
Ahmadi,2011). This questionnaire was chosen as the study instrument because its reliability and validity had been checked by (Al-Ahmadi,2011). The framework, items, validity, and reliability of the questionnaire were also checked by experts and researchers. The questionnaire reliability is $(0.5)$ in $\mathrm{Al}$ Ahmadi's study (2011).In addition, questionnaires can be seen as the most common way of data collection in foreign and second language studies because they are easy to design, completely adaptable, and distinctively accomplished of collecting an outsized amount of data fast (Dörnyei, 2003, p.1). However, using questionnaires might have several drawbacks in different studies and contexts such as giving untruthful information, lack of validity, gaining subjective answers...etc (Ackroyd and Hughes, 1981).

\section{Procedures}

The questionnaire comprised of fifteen different items, each with a five-point Likert scale, which starts with Strongly Agree (1) to Strongly Disagree (5). Likert scales provide a useful outline in applied linguistics and new studies mostly practice the same scale pints in many of the studies on motivation (Busch, 1993; Turner, 1993; Sawada, 2004 or Cheng, Horwitz, and Schallert, 1999) .Eight items measured instrumental motivations and eight different integrative motivation items. The instructions for finishing those questionnaires were clarified by the researcher. The students had thirty minutes to answer the whole questionnaire.

\section{Data Analysis}

The data were collected from the questionnaire; descriptive statistics were examined academically in finding out all the significant features of the findings. The items were demonstrated via tables and the percentage, rank, and coefficient of five Linkert scales were measured and reflected separately for each item. Excel Software was utilized for data analysis.

Table(1)

Instrumental Motivations

\begin{tabular}{|c|c|c|c|c|}
\hline No. & Items & Percentages & $\begin{array}{l}\text { Coefficient } \\
\text { Midst }\end{array}$ & Rank \\
\hline 1 & $\begin{array}{c}\text { I want to travel overseas in the } \\
\text { future. }\end{array}$ & $\% 77$ & 3.8 & 6 \\
\hline 2 & $\begin{array}{l}\text { I want to further my studies in } \\
\text { the future }\end{array}$ & $\% 83$ & 4.1 & 3 \\
\hline 3 & $\begin{array}{l}\text { English can enhance my } \\
\text { chances of immigrating to other } \\
\text { countries in the future. }\end{array}$ & $\% 69$ & 3.4 & 9 \\
\hline 4 & $\begin{array}{c}\text { English is the way to gain more } \\
\text { knowledge. }\end{array}$ & $\% 83$ & 4.1 & 3 \\
\hline 5 & $\begin{array}{c}\text { English can raise my social } \\
\text { status. }\end{array}$ & $\% 79$ & 3.9 & 5 \\
\hline 6 & I want to pass my public exams. & $\% 79$ & 3.9 & 5 \\
\hline 7 & $\begin{array}{l}\text { English can help me to find a } \\
\text { better job in the future. }\end{array}$ & $\% 90$ & 4.5 & 1 \\
\hline
\end{tabular}

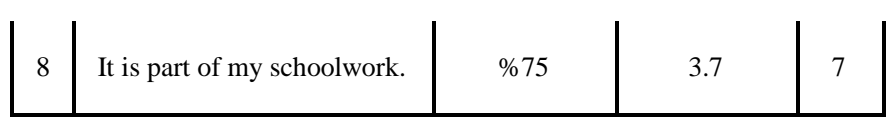

As shown in Table 1, question items 7, 4, and 2 got the top three highest frequencies, rank, and coefficient midst. Question item 3 got the top lowest frequency, rank, and coefficient. Regarding, question item 7, it indicates that Kurdish EFL learners are interested in learning English to find a better job in the future. Kurdish EFL learners seem to be more instrumental because the short survey presents that $90 \%$ of participants want to learn English to develop their future career and find a better job. The results of this study are similar to the findings of Qashoa (2006) and Dörnyei (1990). In their research study, they found out that instrumental motivation can be considered as a major key for motivating students to learn English in EFL contexts whilst integrative motivation is thought to be effective in ESL settings.

Table(2)

Integrative Motivation

\begin{tabular}{|c|c|c|c|c|}
\hline No. & Items & Percentages & $\begin{array}{c}\text { Coefficient } \\
\text { Midst }\end{array}$ & Rank \\
\hline 9 & $\begin{array}{c}\text { English can help me to make } \\
\text { friends with people of different } \\
\text { nationalities and backgrounds. }\end{array}$ & $\% 79$ & 3.9 & 5 \\
\hline 10 & $\begin{array}{c}\text { I want to fit in with native } \\
\text { English speakers. }\end{array}$ & $\% 79$ & 3.9 & 5 \\
\hline 11 & $\begin{array}{c}\text { English can help me understand } \\
\text { Western culture. }\end{array}$ & $\% 83$ & 4.1 & 3 \\
\hline 12 & $\begin{array}{c}\text { It can help me broaden my } \\
\text { horizons. }\end{array}$ & $\% 73$ & 3.6 & 8 \\
\hline 13 & $\begin{array}{c}\text { It can satisfy my interests and } \\
\text { curiosity. }\end{array}$ & $\% 79$ & 3.9 & 5 \\
\hline 14 & $\begin{array}{c}\text { English is the mark of an } \\
\text { educated person }\end{array}$ & $\% 67$ & 3.3 & 10 \\
\hline 15 & $\begin{array}{c}\text { I like conversing with } \\
\text { foreigners. }\end{array}$ & $\% 81$ & 4 & 4 \\
\hline 16 & $\begin{array}{c}\text { I want to pass my public } \\
\text { examinations. }\end{array}$ & $\% 67$ & 3.3 & 10 \\
\hline
\end{tabular}

As shown in Table 2, question items 11, and 15 got the top three highest frequencies, rank, and coefficient midst. Question item 14 got the top lowest frequency, rank, and coefficient. Regarding, question items 11 and 15 they indicate that Kurdish EFL learners are interested in learning English to understand Western culture and conversing with foreigners. Integrative motivation is ranked second among Kurdish EFL learners. 83\% of the learners want to learn English to understand the western culture and $81 \%$ out of 130 students want to learn English to communicate with foreigners. In other words, Kurdish EFL learners may have the opportunity to interact with foreigners in Kurdistan.

Several studies have been conducted to draw a comparison between integrative and instrumental motivational goals among individual learners in different educational settings. Ortega 
(2009, p.176) claims that there are five main reasons for learning languages that L2 learners mostly state such as getting an occupation, being acknowledged by other cultures and their identity, travel purposes, friendship, and other integrative orientations. Similarly, several other reasons for learning English can be identified based on the above-mentioned survey. One hundred and thirty first-year students in morning and evening classes in the English department participated in the College of Basic Education at the University of Sulaimani to reply to the question 'Why do you want to learn English'. This group of students had been chosen since they have attitudes, beliefs, and opinions towards learning English for three years.

Besides, the results can be delineated within the structures of interpreting the concept of 'integrative and instrumental motivation' in an EFL context in the light of describing the English language as a global language (Dörnyei, 2006; Lamb, 2004). This point accords with interpreting the English language in the Kurdish educational context since English is mainly used as an international language. Kurdish EFL learners seem to be more instrumental because the short survey presents that 130 students want to learn English to develop their future career and find a better job. Moreover, there may be an inconsistency with this argument because current studies indicate that learners need both of these types of motivation (Aydin, 2007; Dornynei, 2001; Kaylani, 1996 cited in Oruc and Bektas-Cetinkaya, 2010). This correlates with EFL Malaysian students who are extrinsically and intrinsically motivated to master a foreign language like French (Zubairi and Sarudin, 2009 , p.82). Above all, with the view of a small group of Kurdish EFL learners, it can be stated that instrumental motivation is more momentous than integrative motivation since $90 \%$ of Kurdish EFL learners want to learn English to use it in their future careers. The results of the present study are congruent with the findings of Oruç and Bektas-Çetinkaya, (2010) study. They found that 108 out of 228 Turkish learners show the same motivation to learn English as well. Furthermore, Spratt and Humphreys (2008, p.313) claim that students in Hong Kong are more instrumentally motivated in learning English. Correspondingly, learners can have instrumental motivation as a practical guide for the achievement of occupations (Norton, 1995, 2000). In brief, instrumental motivation appears to be the most influential variable in the Kurdish EFL context.

On the other hand, integrative motivation is placed second among Kurdish EFL learners. $81 \%$ of students want to learn English to communicate with foreigners. This integration is possibly common among Kurdish EFL learners since most of them try to be accepted by native speakers of the English language to be acknowledged by an English culture or community. In other words, Kurdish EFL learners may have the chance to interact with foreigners in Kurdistan. This corresponds with the view of (Oruç; Bektas-Çetinkaya, 2010, p.4664) reveals that learners can converse with the global population with worldwide languages such as English. The importance of integrative motivation might vary from one environment to another. As it is argued that, for Malaysians, the most vital reasons for learning a foreign language are meeting and conversing with people from various backgrounds and participating in other cultural activities (Gonzales, 2010, p.17). This is compatible with the second reason among Kurdish EFL learners to learn English owing to interacting with English culture and community. Nevertheless, the English language community is not like India. Some other learners assay to participate in activities with English foreigners. Further, another study from Lebanon shows weak integrative motivation among university students to learn English (Diab, 2006, p.80). Non-Muslim Malaysian learners also appear to be less interactively motivated in learning Arabic in Malaysia (Aladdin, 2010, p.1805). These findings partially correlate with the integrative motivation atmosphere among Kurdish EFL learners.

Based on the findings, it can be claimed that instrumental motivation might be more important than integrative motivation in the Kurdish EFL educational setting. However, it is sometimes difficult to make a precise differentiation between these two constructs. Similarly, learners' motivation cannot be classified into integrative and instrumental motivation since they often show characteristics of both (Oruç; BektasÇetinkayaa, 2010, p.4664).

\section{CONCLUSION}

It can be summarized that motivation is an effective construct that can work differently in educational settings. Several studies have shown that motivation works in ESL and EFL contexts. Besides, motivation has appeared as a vital construct in several educational and psychological studies. Kinds of motivation indicate learners' reasons for learning languages particularly, instrumental motivation in the Kurdish EFL context. The importance of international languages such as English and Arabic would motivate learners to learn languages. Moreover; learners have various reasons for learning English in the Kurdish EFL context. It is thought that professional goals such as finding a job are more workable than any other goals in the Kurdish EFL context. Nonetheless, communication and cultural goals represent the second and third importance. This study shows that Kurdish EFL learners bring stronger instrumental motivation than integrative motivation to learn the English language. The greater part significant elements influence students' motivation needs aid parents, teachers, social personality, and university environment. Kurdish learners were found to have stronger instrumental motivation than integrative motivation. It is believed that Kurdish EFL teachers should employ doable plans and modify their teaching techniques and pedagogical implications in order to practice instrumental and integrative motivations amongst Kurdish EFL learners at different levels.

\section{PEDAGOGICAL IMPLICATIONS}

Findings of the present study bring significance to Kurdish EFL students and the instructional method in the EFL setting. 
Based on the findings, it is thought that teachers should employ and modify some instructional methods and techniques in different ways. Firstly, teachers should emphasize expanding students' integrative and instrumental motivations, despite findings of the study point out that Kurdish EFL learners have stronger instrumental motivation than integrative motivation on language learning. Secondly, teachers should catch on to fitting exercises that improve students' motivation. Teachers should also utilize viable methodologies to motivate learners of diverse groups. Additionally, they could advise their learners about the importance of furthermore convenience about these methodologies. Also, teachers should modify their teaching methods built on their learners' needs and motivations in order to facilitate learning English. Finally, learners at different levels of abilities are encouraged by both integrative and instrumental motivation and both sorts of motivation should be stimulated in the classroom by teachers. As a result, learners can practice and find their reasons for learning English inside and outside the classroom.

\section{ACKNOWLEDGMENT RECOMMENDATION FOR FUTURE STUDIES}

The present study concentrated on Kurdish EFL learners at the university level and particularly amongst first-year learners. The two kinds of motivation need to be investigated broadly amongst Kurdish EFL learners at higher levels of study. In particular, researchers can investigate the same topic amongst second, third and fourth year Kurdish EFL undergraduate learners in English and non-English departments. Namely, to address the effectiveness of motivations properly, it is highly recommended to investigate all reasons for learning English amongst male and female learners due to showing differences between the two genders.

\section{REFERENCES}

Ackroyd, S., and Hughes, J.A. (1981) Data collection in context. Longman

Al-Ahmadi, M. R. (2011). The Effect of Integrative and Instrumental Motivation on Iranian EFL Learners' Language Learning. ELT Voices- India, 97-104.

Aladdin, A. (2010). Non-Muslim Malaysian learners of Arabic (NMMLAs): An investigation of their attitudes and motivation towards learning Arabic as a foreign language in multiethnic and multicultural Malaysia. Procedia Social and Behavioral Sciences 9, 1805-1811.

Al Rifai, N. (2010). Attitude, motivation, and difficulties involved in learning the English language and factors that affect motivation in learning it. Procedia Social and Behavioral Sciences, 2, 52165227.

Aydin, E. (2007). An Analysis of Motivations, Attitudes, and Perceptions of the Students at TOBB University of Economics and Technology

toward Learning English as a Foreign Language. Unpublished Master's Thesis, Hacettepe University, Ankara.

Baumeister, R., and Leary, M. R. (1995). The need to belong: Desire for interpersonal attachments as a fundamental human motivation. Psychological Bulletin, 117, 497-529.

Bernard, J. (2010).Motivation in Foreign Language Learning: the relationship between Classroom Activities, Motivation, and
Outcomes in a University Language- Learning Environment. MA. Carnegie Mellon University.

Bonney, et al. (2008). Understanding strategies in foreign language learning: Are integrative and intrinsic motives distinct predictors? Learning and Individual differences, 18, 1-10.

Brown, D. (1994). Principles of language learning and teaching (3rd ed.). Englewood Cliffs, NJ: Prentice Hall Regents.

Busch, M. (1993). Using Likert scales in L2 research: A researcher comments... TESOL

Quarterly, 27(4), 733-736.

Cheng, Y., Horwitz, E. K., \& Schallert, D. L. (1999). Language anxiety: Differentiating writing and speaking components. Language Learning, 44(3), 471-446.

Clément, R., Dörnyei, Z., \& Noels, K. A. (1994). Motivation, selfconfidence, and group cohesion in the foreign language classroom. Language Learning, 44(3), 417-448. https://doi.org/10.1111/j.1467-1770.1994.tb01113.x

Crystal, D.(2007). How language works: How babies babble, words change meaning and languages live or die. London: Penguin.

Csikszentmihalyi, M., \& Nakamura, J. (1989). The dynamics of intrinsic motivation: A study of adolescents. In R. Ames \& C. Ames (Eds.), Research on motivation in education: Goals and cognitions (pp.45-71). New York: Academic Press.

Deci, E. L., \& Ryan, R. M. (1985). The general causality orientations scale: Self-determination in personality. Journal of Research in Personality, 19, 109-134.

Deci, E. L., \& Ryan, R. M. (1987). The support of autonomy and the control of behavior.Journal of Personality and Social Psychology, 53 1024-1037.

Diab, R. L. (2006). University students' beliefs about learning English and French in Lebanon. System $34,80-96$.

Dörnyei, Z. (1990). Conceptualizing motivation in foreign language learning.Language Learning, 40, 46-78.

Dörnyei, Z. (2005). The psychology of the language learner: Individual differences in second language acquisition. Mahwah, NJ: Lawrence Erlbaum.

Dörnyei, Z. (2006). Individual differences in second language acquisition. AILA Review, 19, 42-68.

Dörnyei, Z. (2001). Teaching and Researching Motivation. Essex: Pearson Education Ltd.

Dörnyei,Z. (2003). Questionnaires in second language research: construction, administration, and processing. Mahwah, NJ: Lawrence Erlbaum.

Ebong, B. (2004). The use of indigenous techniques of communication in language learning: the case of Cameroon. Gottingen: Guvillier Verlag.

Gardner, R. C. (1985). Social psychological aspects of language learning: The role of attitudes and motivation. London: Edward Arnold.

Gardner, R.C. (2000). Correlation, causation, motivation and second language acquisition. Canadian Psychology 41, 1-24.

Gardner, R.C. (2001). Integrative motivation and second language acquisition. In: Do" rnyei, Z., Schmidt, R. (Eds.), Motivation and Second.Language Acquisition.

Gardner, W. L., Avolio, B. J., Luthans, F., May, D. R., \& Walumba, F. O. (2005). Can you see the real me? A self-based model of authentic leader and follower development. The Leadership Quarterly University of Hawai'i, Second Language Teaching and Curriculum Centre, Honolulu, pp. 1-19.

Gardner, R. C. (2007). Motivation and second language acquisition. Porta Linguarum 8, pp.9-20. 
Gardner, R.C., Lalonde, R., \& Pierson, R. (1983). The socio-educational model of second language acquisition: An investigation using LISREL causal modeling. Journal of Language and Social Psychology, 2, 51-65

Gardner, R.C. \& Lambert, W.E. (1972). Motivational variables in second language acquisition. In R.C. Gardner \& W. Lambert (eds.) Attitudes and motivation in second language learning. (pp. 119216). Rowley, MA: Newbury House.

Gardner, R. C. (1988). The socio-educational model of second language learning: Assumptions, findings, and issues. Language Learning, 38,101-126.

Giles, H. and Byrne, J. L. (1982) An intergroup approach to second language acquisition. Journal of Multilingual and Multicultural Development, 3, 17-40.onzales, Richard DLC., 2010. Motivational orientation in a foreign language: the case of Filipino foreign language learners. TESOL Journal, (3), pp. 3-28.

Gu (Michelle), M. (2009). College English learners' discursive motivation construction in China. The system, 37 ,300-312.

Hama S. P., payman_sabir@yahoo.com, (2011). A short survey among third-year students at The College of Basic Education' Why do you want to learn to English'. [email] message to FarhadHama( farhadengland@gmail.com). Sent Wednesday 21 December 2011, 02:40. [Accessed 7 Jan 2012].

Johnson, Keith. 2008. An introduction to foreign language learning and teaching. Harlow: Longman.

Kaylani, C. (1996). The influence of gender and motivation on EFL learning strategy use in Jordan. In Oxford, R. L. (Ed.), Language Learning Strategies Around the World: Cross-cultural Perspectives. University of Hawaii: Honolulu.

Khajehpour, M., and Ghazvini, S. D. (2011). Attitudes and Motivation in learning English as a Second Language in high school students. Procedia Social and Behavioral Sciences 15, 1209-1213.

Koul, et al. (2009). Multiple goal orientations and foreign language anxiety. System 37, 676-688. Lamb, Martin., 2004. Integrative motivation in a globalizing world. System, 32, 3-19.

Lamb, M. (2004). Integrative motivation in a globalizing world. System, 32, 3-19.

Lewis, M. (2011). How to study foreign languages. Basingstoke: Macmillan Macmillan, 2011. Sunrise: A bright new look at English. [online] available at < http://www.sunrisekurdistan.com/sunrise secondary/testing/level-7/> [Accessed 15 Jan 2012].

Masgoret, A.M., and Gardner, R.C. (2003). Attitudes, motivation, and second language learning: A meta-analysis of studies conducted by Gardner and Associates. Language Learning, 53 (1), 123 -163.

Manolopoulou-Sergi, E. (2004). Motivation within the information processing model of foreign language learning. System 32, 427441.

Noles, K.A., Clement, R., Pelletier, L.G. (1999). Perceptions of teachers' communicative style and students' intrinsic and extrinsic motivation. The Modern Language Journal, 83, 23-34.
Norton Peirce, B. (1995). Social identity, investment, and language learning. TESOL Quarterly, 29 (1), 9-3

Norton, B.(2000). Identity and language learning: Social processes and educational practice.Longman: London.

Norton, B. (2000). Identity and Language Learning: Gender, Ethnicity and Educational Change. Harlow: Pearson Education.

Ortega, L. (2009). Understanding second language acquisition. London: Hodder Education.

Oruç, N., and Bektas-Çetinkayaa, Y.(2010). Turkish students' motivation to learn English at public and private universities. Procedia Social and Behavioral Sciences 2, 4662-4666.

Oxford, R. L. (1990). Language learning strategies: What every teacher should know. Boston, MA: Heinle \& Heinle.

Qashoa, S. (2006). Motivation among learners of English in the secondary schools in the eastern coast of the UAE. M.A thesis, British University in Dubai.

Ryan, R. M., and Deci, E. L. (2000). Self-determination theory and the facilitation of intrinsic motivation, social development, and wellbeing. American Psychologist, 55, 68-78.

Sarudin, I. H., and Zubairi, A. M. (2009). Motivation to Learn a Foreign Language In Malaysia. GEMA Online Journal of Language Studies, 9(2),73-87.

Sawada, M. (2004). Adult EFL learner motivation: Learning English as lifelong learning. JACET Bulletin, 39, 59-71.

Schumann, J. H. (1986). Research on the acculturation model for second language acquisition. Journal of Multilingual and Multicultural Development, 7 (5), 379-392.

Scott, J. C. S. D. Y., and Laurie, K. ed., (2009). Affirming students' right to their language. New York: Routledge.

Spratt, M. and Humphreys, G. (2008). Many languages, many motivations: A study of Hong Kong students' motivation to learn different target languages. System, 36, 313-335.

Spolsky, B. (1989). Conditions for Second Language Learners. Oxford: Oxford University Press

Turner, J. (1993). Using Likert scales in L2 research: Another researcher comments... TESOL Quarterly, 27(4), 736-739.

William M. B. R L. (2000). Psychology for Language Teachers. Cambridge University Press, Foreign Language Teaching and Research Press, People's Education Press.Ortega, Lourdes., 2009. Understanding second language acquisition. London: Hodder Education.

Yashima, T. (2002). Willingness to communicate in a second language: the Japanese EFL context. The Modern Language Journal,86, 54-66. 